\title{
USP28 wt Allele
}

National Cancer Institute

\section{Source}

National Cancer Institute. USP28 wt Allele. NCI Thesaurus. Code C124090.

Human USP28 wild-type allele is located in the vicinity of $11 \mathrm{q} 23$ and is approximately 78 $\mathrm{kb}$ in length. This allele, which encodes ubiquitin carboxyl-terminal hydrolase 28 protein, is involved in the DNA damage checkpoint and protein deubiquitination. 